\title{
Minerals and heavy metals in Labisia pumila var. alata folia of Selected Geographic Origins
}

\author{
Ade Chandra Iwansyah ${ }^{1, *}$, Noorazizah Zainal Abidin ${ }^{2}$, Mashitah Mohammad Yusoff ${ }^{3}$ \\ ${ }^{1}$ Research Centre for Appropriate Technology, Indonesian Institute of Sciences, \\ KS Tubun No. 5, Subang 41213, West-Java-Indonesia \\ ${ }^{2}$ Central Analytical Laboratories, Universiti Malaysia Pahang, 26300 Gambang, Pahang, Malaysia \\ ${ }^{3}$ Faculty of Industrial Sciences \& Technology, Universiti Malaysia Pahang, 26300 Gambang, Pahang, Malaysia \\ *Corresponding author: chandra.iwansyah@gmail.com
}

DOI: https://doi.org/10.26874/jkk.v2i1.25

Received: 10 May 2019, Revised: 31 May 2019, Accepted: 31 May 2019, Online: 31 May 2019

\begin{abstract}
Labisia pumila var. alata leaves (LP) with a long history of use folk remedy and endemic to the Malay Archipelago, is now supplied worldwide as ingredient of functional foods and beverages. Minerals and heavy metal concentrations in Labisia pumila var. alata folium (LP) of selected geographic origin based on microwave-assisted sample digestion and inductively coupled plasma mass spectrometry (ICP-MS) were determined. Fifteen elements comprising minerals (Ba, Ca, Cr, Co, Cu, Fe, K, Mg, Na, Ni, $\mathrm{Rb}$ and $\mathrm{Zn}$ ) and heavy metals ( $\mathrm{As}, \mathrm{Cd}$ and $\mathrm{Pb}$ ) were analyzed with an inductively coupled plasma - mass spectrometer (ICP-MS). The highest nutrient concentration was measured in LP from Tilu Mountain $(\mathrm{Cu}, \mathrm{Na}, \mathrm{K}, \mathrm{Mg}$ and $\mathrm{Zn}$ ). The highest values of $\mathrm{Ba}, \mathrm{Ca}, \mathrm{Co}, \mathrm{Cr}$ and $\mathrm{Fe}$ were detected in $\mathrm{LP}$ from Raub. $\mathrm{Ni}$ and $\mathrm{Rb}$ were highest in LP from Cibeundey Village. As was highest in LP from Raub $(0.04 \pm 0.00$ $\mathrm{mg} / \mathrm{kg})$. The highest $\mathrm{Pb}$ contents were in LP from Tilu Mountain $(2.90 \pm 0.10 \mathrm{mg} / \mathrm{kg})$ and LP from Halimunan-Salak Mountain $(3.12 \pm 0.03 \mathrm{mg} / \mathrm{kg})$, all of which were well within the permissible limits as specified by the U.S. FDA for edible plant parts.
\end{abstract}

Keywords: heavy metals, inductively coupled plasma-mass spectrometry, Labisia pumila var. alata folia, microwave-assisted sample digestion, minerals

\section{Introduction}

Plants constitute an important link in the transfer of minerals and heavy metals from soil to man. A beneficial level of these elements in humans is required to maintain good health. Since raw plant materials are increasingly used as ingredients of dietary supplements, data on minerals and heavy metal contents are required by regulatory agencies due to nutritional as well as toxicological implications [1]. Quality control monitoring should ensure the safety, efficacy and quality of the raw plant material [2]. While, there are no standards for such raw plant materials, the Food \& Drug Administration of the United States (USFDA) mentions maximum permissible levels in edible plant parts for lead, cadmium and arsenic which amount to $10,0.3$ and $1.0 \mathrm{mg} / \mathrm{kg}$, respectively [3].
Plant materials have been analyzed for different elements using techniques such as atomic emission spectrometry (AES), atomic absorption spectrometry (AAS), induced coupled plasma atomic emission (ICP-AES) and induced coupled plasma mass spectrometry (ICP-MS). Obtaining reproducible results present a challenge as analytes are present in low levels in high matrix samples such as plants. ICP-MS is becoming one of the most widely used techniques for the determination of elements at trace and ultra-trace level (ppb, ppt), owing to low detection limits, multi-elemental capacity and wide linear range. A recent validation study based on selected criteria of performance demonstrated that the use of both microwave digestion in closed-vessel for sample preparation and the ICP-MS for detection permitted an accurate determination of matrices of animal and plant origin [4]. 
Labisia pumila (Malay: kacip fatimah) is a herbaceous plant, endemic to the rainforests of the Malay Archipelago. Traditionally, Labisia pumila var. alata folia (LP) is used in the form of a decoction as postpartum tonic [5]. Today, the demand for LP has expanded beyond the regional dietary supplements market, increasing the need for several sources of supply. Results of a recent study found that extracts of LP affect 11- $\beta$ dehydrogenase 1 expressions in both adipose and liver tissues while decreasing circulating corticosterone [6]. This implies the potential of LP extracts as a natural remedy for weight management. There is, however, a paucity of published studies on nutrient and heavy metal constituents in LP. In the present work, minerals (Ba, $\mathrm{Ca}, \mathrm{Cr}, \mathrm{Co}, \mathrm{Cu}, \mathrm{Fe}, \mathrm{K}, \mathrm{Mg}, \mathrm{Na}, \mathrm{Ni}, \mathrm{Rb}$ and $\mathrm{Zn}$ ) and heavy metals ( $\mathrm{As}, \mathrm{Cd}$ and $\mathrm{Pb}$ ) in $\mathrm{LP}$ were determined by means of the ICP-MS method.

The objectives of this study were to determine the distribution of minerals and toxic elements in LP, to determine whether the safety limits had been exceeded and to compare these findings with results on LP collected from different geographic origins between Malaysia and Indonesia (Table 1).

Table 1. Sources of Labisia pumila var.alata.

\begin{tabular}{|l|l|l|}
\hline Code & Altitude (msl) & Location \\
\hline LPR & $300-400$ & Raub, Pahang \\
\hline LPB & 600 & Halimun-Salak Mountain, Bogor District, West Java \\
\hline LPT & $600-700$ & Tilu Mountain, Bogor District, West Java \\
\hline LPA & 300 & Cibeundey Village, South Aceh District, Aceh Province \\
\hline LPL & 150 & Pekandangan Village, Middle-Lampung District, Lampung Province \\
\hline
\end{tabular}

msl: meters above sea level

\section{Material and Methods}

\subsection{Reagents}

Reagents used were of analytical grade. Plant digests were prepared using $\mathrm{HNO}_{3}$ (Merck, Darmstadt, Germany) and 30\% v/v $\mathrm{H}_{2} \mathrm{O}_{2}$ (Merck, Darmstadt, Germany). Hydrophyllic PVDF Millipore Millex-HV filters were used. Doubly deionized water was obtained using an ELGA Purelab Option-Q DV 25 (UK). Plastic bottles were cleaned by soaking in $10 \% \mathrm{v} / \mathrm{v} \mathrm{HNO}_{3}$ for 24 hours and rinsed abundantly in doubly deionized water before use. Teflon materials were immersed in freshly prepared $20 \% \mathrm{v} / \mathrm{v} \mathrm{HNO}_{3}$ overnight and thoroughly rinsed with $5 \% \mathrm{v} / \mathrm{v} \mathrm{HNO}_{3}$ prior to use. Stock standard solutions of individual metals (1000 mg/L) were supplied by Merck.

\subsection{Instrumentation and parameters}

Elements in LP in this study were determined by a quadrupole-based ICP-MS (ICP-QMS, Agilent 7500a Series). The plant samples were investigated with respect to accumulation and distribution of the nutrient elements $\mathrm{Al}, \mathrm{Ba}, \mathrm{Ca}$, $\mathrm{Cr}, \mathrm{Co}, \mathrm{Cu}, \mathrm{Fe}, \mathrm{K}, \mathrm{Mg}, \mathrm{Na}, \mathrm{Ni}, \mathrm{Rb}$ and $\mathrm{Zn}$ and heavy metals $\mathrm{As}, \mathrm{Cd}$ and $\mathrm{Pb}$ under optimized experimental parameters as summarized in Table 2.
Table 2. Operating conditions for ICP-MS

\begin{tabular}{ll}
\hline Instrument & Agilent 7500a \\
\hline Nebulizer & Babington type \\
Spray & Scott-type \\
chamber &
\end{tabular}

\begin{tabular}{ll}
\hline Plasma & \\
\hline RF generator & $\begin{array}{l}\text { Frequency: } 10 \mathrm{MHz}, \text { Power } \\
\text { output } 1300 \mathrm{~W}\end{array}$ \\
Ar flow rate & $\begin{array}{l}\text { Plasma: } 15, \text { auxiliary: } 0.9 \\
\text { nebulizer: } 1-1.1\end{array}$ \\
Solution & $1.8 \mathrm{ml} / \mathrm{min}$ \\
uptake rate &
\end{tabular}

\begin{tabular}{ll}
\hline Interface & \\
\hline Sample cone & Nickel, id $1.1 \mathrm{~mm}$ \\
Skimmer & Nickel, id $0.9 \mathrm{~mm}$ \\
Vacuum & Interface: 4 torr, quadrupole: \\
& $2 \times 10^{-5}$ torr \\
Data & Peak hopping, replicate time \\
acquisition & 200 ms, dwell time $200 \mathrm{~ms}$, \\
& sweeps/reading \\
& readings/replicate 3 \\
Analytical & ${ }^{23} \mathrm{Na},{ }^{24} \mathrm{Mg},{ }^{39} \mathrm{~K},{ }^{40} \mathrm{Ca},{ }^{53} \mathrm{Cr}$, \\
masses & ${ }^{57} \mathrm{Fe},{ }^{58} \mathrm{Ni},{ }^{59} \mathrm{Co},{ }^{60} \mathrm{Cu},{ }^{66} \mathrm{Zn}$, \\
& ${ }^{75} \mathrm{As},{ }^{85} \mathrm{Rb},{ }^{111} \mathrm{Cd},{ }^{138} \mathrm{Ba},{ }^{208} \mathrm{~Pb}$ \\
\hline
\end{tabular}




\subsection{Sample preparation}

LP in this study was collected from various study sites between Malaysia and Indonesia. Plant samples were identified by Herbarium Bogoriense (Indonesian Institute of Sciences). LP were rinsed to remove debris, dried at $40^{\circ} \mathrm{C}$ for 3 days and ground into powder.

\subsection{Sample digestion}

Samples were prepared by accurately weighing approximately $0.5 \mathrm{~g}$ LP powder into a modified Teflon digestion vessel, to which was added exactly $7 \mathrm{ml}$ of $65 \%$ solution of $\mathrm{HNO}_{3}$ and $1 \mathrm{ml}$ of $30 \%$ solution of $\mathrm{H}_{2} \mathrm{O}_{2}$. Samples were acid digested with microwave-assisted irradiation using the Milestone Ethos One ATC-FO 300. Duration of heating was 20 minutes at $300 \mathrm{~W}$. Upon cooling, the vessel content was transferred into a $50 \mathrm{~mL}$ volumetric flask. Samples were diluted and filtered through a Hydrophyllic PVDF Millipore Millex-HV prior to analysis. Standard metal solutions were prepared directly from the $1000 \mathrm{mg} / \mathrm{l} \mathrm{stock}$ of $2 \% \mathrm{v} / \mathrm{v} \mathrm{HNO}_{3}$.

\subsection{Method detection limit}

Six blank samples were digested and each of the samples analyzed for metal concentration by ICP-MS. The standard deviations $(3 \sigma)$ for each element were calculated from the six blank measurements (measured three times) to determine detection limit of the method.

\subsection{Statistical analysis}

The experimental results are expressed as mean standard deviation (SD) of replicate measurements. The results were processed using Microsoft Excel 2013 and the data were subjected to one way analysis of variance (ANOVA) and the significance of differences between sample means were calculated by Duncan's multiple range test using SPSS for Windows (Standard Version 15.00, SPSS Inc., Chicago, IL). P values $\leq 0.05$ were regarded as significant and $\mathrm{P}$ values $\leq 0.01$ as very significant.

\section{Results and Discussion \\ 3.1 Minerals and heavy metals}

Determination of minerals and heavy metals in this study, were carried out using Inductively Coupled Plasma - Mass Spectrometer (ICP-MS). A calibration graph was constructed using five concentrations $(0-500 \mu \mathrm{g} / \mathrm{L})$ covering the ranges expected in the various samples. Based on data obtained, the quantities of the minerals and heavy metals contribution by each sample were compared. Table 3 lists concentration of minerals of LP sourced from different geographic origins between Malaysia and Indonesia.

Table 3. Mean concentration of minerals in different samples

\begin{tabular}{lcccccc}
\hline Minerals & $\begin{array}{c}\text { LPR } \\
(\mu \mathbf{g} / \mathbf{k g})\end{array}$ & $\begin{array}{c}\text { LPB } \\
(\mu \mathbf{g} / \mathbf{k g})\end{array}$ & $\begin{array}{c}\text { LPT } \\
(\mu \mathbf{g} / \mathbf{k g})\end{array}$ & $\begin{array}{c}\text { LPA } \\
(\mu \mathbf{g} / \mathbf{k g})\end{array}$ & $\begin{array}{c}\text { LPL } \\
(\mu \mathbf{g} / \mathbf{k g})\end{array}$ & $\begin{array}{c}\text { RNI } \\
(\mathbf{p e r} \text { day })\end{array}$ \\
\hline $\mathrm{K}$ & 8102.0 & 6016.0 & 11280.0 & 8720.0 & 6625.0 & $3500 \mathrm{mg}$ \\
$\mathrm{Mg}$ & 2104.0 & 2789.0 & 4761.0 & 3491.0 & 2946.0 & $350 \mathrm{mg}$ \\
$\mathrm{Ca}$ & 2658 & 1459.0 & 1789.0 & 1910.0 & 1340 & $1000 \mathrm{mg}$ \\
$\mathrm{Na}$ & 61.49 & 132.6 & 202.0 & 42.19 & 32.89 & $2400 \mathrm{mg}$ \\
$\mathrm{Cr}$ & 9.29 & 0.29 & 0.64 & 0.20 & 2.65 & $120 \mu \mathrm{g}$ \\
$\mathrm{Fe}$ & 426.1 & 141.9 & 346.7 & 59.62 & 69.37 & $15 \mathrm{mg}$ \\
$\mathrm{Co}$ & 1.78 & 0.39 & 0.37 & 0.57 & 0.53 & $\mathrm{n} . \mathrm{a}$. \\
$\mathrm{Cu}$ & 3.46 & 2.9 & 4.58 & 3.83 & 3.78 & $2 \mathrm{mg}$ \\
$\mathrm{Zn}$ & 10.69 & 15.37 & 23.2 & 9.63 & 13.70 & $15 \mathrm{mg}$ \\
& 19.64 & 21.71 & 33.05 & 41.1 & 34.09 & $\mathrm{n} . \mathrm{a}$. \\
$\mathrm{Rb}$ & 21.38 & 7.91 & 7.62 & 16.47 & 12.04 & $\mathrm{n} . \mathrm{a}$. \\
$\mathrm{Ba}$ & 5.61 & 0.83 & 2.17 & 4.64 & 4.09 & $<1 \mathrm{mg}$ \\
$\mathrm{Ni}$ &
\end{tabular}

" Recommended nutrient intake (RNI) for adults ages 19-65 years old (WHO) Measurements: average ( $n=6) ;$ n.a. = not available 
The abundance of $\mathrm{K}, \mathrm{Mg}$ and $\mathrm{Ca}$, in the result of this analysis, was in agreement with previous findings that these three metals represent the most abundant metal constituents of many plants [7]. The average content of potassium $(\mathrm{K})$ ranged between $601.6-1128.0 \mathrm{mg} / 100 \mathrm{~g}$. The average content of calcium $(\mathrm{Ca})$ ranged between 134.0$265.8 \mathrm{mg} / 100 \mathrm{~g}$. LPR contained the highest concentration of calcium $(265.8 \mathrm{mg} / 100 \mathrm{~g})$. The average content of magnesium $(\mathrm{Mg})$ ranged between 210.4 to $476.1 \mathrm{mg} / 100 \mathrm{~g}$. LPT (476.1 $\mathrm{mg} / \mathrm{g}$ ) contained the highest concentration of magnesium. The average content of sodium $(\mathrm{Na})$ in LPT was relatively high $(20.2 \mathrm{mg} / 100 \mathrm{~g})$. LPT $(1128 \mathrm{mg} / 100 \mathrm{~g})$ contained the highest potassium. Sodium and potassium are the principle cations in intracellular fluid, regulating nerve and muscle function, and $\mathrm{Na}^{+} / \mathrm{K}^{+}$-ATPase; while calcium and magnesium, the constituents of bones and teeth and magnesium, an enzyme cofactor [8].

Fe content ranged between $59.62 \mathrm{mg} / 100 \mathrm{~g}$ in LPA to $426.1 \mathrm{mg} / 100 \mathrm{~g}$ in LPR. The average content of iron $(\mathrm{Fe})$ in LPR was highest (426.1 $\mathrm{mg} / 100 \mathrm{~g})$. Fe is a constituent of heme enzymes such as hemoglobin and cytochromes [9]. WHO (2002) mandates the RNI for consumption of $\mathrm{Fe}$ as $15-20 \mathrm{mg}$ per day as deficiency will cause anemia. Cr ranged from $0.20 \mathrm{mg} / 100 \mathrm{~g}$ in LPA to $9.29 \mathrm{mg} / 100 \mathrm{~g}$ in LPR. The average content of chromium (Cr) in LPR was highest (9.29 $\mathrm{mg} / 100 \mathrm{~g}$ ). Cr is implicated in sugar metabolism in human [10]. Trivalent $\mathrm{Cr}$ is a constituent of glucose tolerance factor which binds to and potentiates insulin [8].

The average content of copper $(\mathrm{Cu})$ ranged from $2.90 \mathrm{mg} / 100 \mathrm{~g}$ in $\mathrm{LPB}$ to $4.58 \mathrm{mg} / 100 \mathrm{~g}$ in LPT. The recommended nutrient intake (RNI) for adults ages 19-65 years old (WHO) is $2 \mathrm{mg} /$ day. $\mathrm{Cu}$ is a constituent of oxidase enzymes and plays a role in iron absorption [8]. The average content of cobalt $(\mathrm{Co})$ ranged between $0.27 \mathrm{mg} / 100 \mathrm{~g}$ in LPT to $1.78 \mathrm{mg} / 100 \mathrm{~g}$ in LPR. LPR contained the most $\mathrm{Co}$ at $0.18 \mathrm{mg} / 100 \mathrm{~g}$. Co is an essential constituent of vitamin $B_{12}$. The amount of cobalt in blood is dependent on the amount that is in the soil, and where foods are grown [11]. The average content of zinc $(\mathrm{Zn})$ ranged between $0.96 \mathrm{mg} / 100 \mathrm{~g}$ in LPA to $2.32 \mathrm{mg} / 100 \mathrm{~g}$ in LPT. LPT contained relatively high amount of $\mathrm{Zn}$ at $2.32 \mathrm{mg} / 100 \mathrm{~g}$. The recommended nutrient intake (RNI) for adults ages 19-65 years old (WHO) is $15 \mathrm{mg} / \mathrm{day}$. Zinc is required in the diet for a wide range of biological functions such as components of enzymatic and redox systems, regulating synthesis and transcriptions proteins [12].

Non-essential minerals are other trace minerals not yet recognized by the health authorities, but which are believed to be essential for human health. The average content of $\mathrm{Rb}$ in LPA was highest $(41.10 \mu \mathrm{g} / \mathrm{g})$ compared to the other samples. The average content of Ba ranged between $7.62 \mu \mathrm{g} / \mathrm{g}$ (LPT) - $21.38 \mu \mathrm{g} / \mathrm{g}$ (LPR). The average content of Ni ranged $0.83 \mu \mathrm{g} / \mathrm{g}$ in LPB to $5.61 \mu \mathrm{g} / \mathrm{g}$ in LPR.

Among the heavy metals, lead $(\mathrm{Pb})$, cadmium (Cd) and arsenic (As) are especially toxic and are harmful to humans even at low concentrations. They have an inherent toxicity with a tendency to accumulate in the food chain and a particularly low removal rate through excretion [13]. Exposure to heavy metals above the permissible level can cause high blood pressure, fatigue, as well as kidney and neurological disorders. Heavy metals are also known to cause harmful reproductive effects [14]. Like all plant raw materials, LP is regulated in terms of standard limitation of heavy metal content. The concentration of heavy metals is one of the criteria according to which raw plant materials can be used in the production of functional foods and beverages. Table 4 shows that all samples under investigation accumulated heavy metals (As, $\mathrm{Cd}$, and $\mathrm{Pb}$ ) at a level appreciably below the permissible level in edible plant parts as mentioned by the Food \& Drug Administration of the United States (USFDA). Based on the results obtained, LP may be included as an important source of minerals for daily consumption.

Table 4. Mean concentration of heavy metals in different samples

\begin{tabular}{lcccccc}
\hline $\begin{array}{l}\text { Heavy } \\
\text { Metal }\end{array}$ & $\begin{array}{c}\text { LPR } \\
(\mu \mathrm{g} / \mathrm{kg})\end{array}$ & $\begin{array}{c}\text { LPB } \\
(\mu \mathrm{g} / \mathrm{kg})\end{array}$ & $\begin{array}{c}\text { LPT } \\
(\mu \mathrm{g} / \mathrm{kg})\end{array}$ & $\begin{array}{c}\text { LPA } \\
(\mu \mathrm{g} / \mathrm{kg})\end{array}$ & $\begin{array}{c}\text { LPL } \\
(\mu \mathrm{g} / \mathrm{kg})\end{array}$ & $\begin{array}{c}\text { USFDA } \\
(\mathrm{mg} / \mathrm{day})\end{array}$ \\
\hline $\mathrm{As}$ & 0.04 & $<0.00$ & $<0.00$ & $<0.00$ & $<0.00$ & 1.0 \\
$\mathrm{Cd}$ & $<0.00$ & $<0.00$ & $<0.00$ & $<0.00$ & $<0.00$ & 0.3 \\
$\mathrm{~Pb}$ & 1.10 & 3.12 & 2.9 & 0.41 & 1.67 & 10 \\
\hline
\end{tabular}




\subsection{The limit of detection}

Microwave digestion and ICP-MS analysis has been established and used for the determination of 12 minerals and 3 heavy metals, in samples of LP of selected geographic origins. Samples collected were found to give distinct distribution patterns of trace elements.

The method has been validated using certified reference material, assessing its quality in terms of accuracy, repeatability and detection limit (Table 5). The results obtained show the validity of the method used.

Table 5. LOD of methods in determining minerals and heavy metals

\begin{tabular}{cc}
$\begin{array}{c}\text { Minerals } \\
\text { \& Heavy Metals }\end{array}$ & $\begin{array}{c}\text { Method } \\
\text { detection limit } \\
(\boldsymbol{\mu g} / \mathbf{k g})\end{array}$ \\
\hline $\mathrm{K}$ & 0.015 \\
$\mathrm{Mg}$ & 0.004 \\
$\mathrm{Ca}$ & 0.060 \\
$\mathrm{Na}$ & 0.005 \\
$\mathrm{Cr}$ & 0.003 \\
$\mathrm{Fe}$ & 0.074 \\
$\mathrm{Co}$ & 0.058 \\
$\mathrm{Cu}$ & 0.042 \\
$\mathrm{Zn}$ & 0.012 \\
$\mathrm{Rb}$ & 0.050 \\
$\mathrm{Ba}$ & 0.090 \\
$\mathrm{Ni}$ & 0.030 \\
$\mathrm{As}$ & 0.022 \\
$\mathrm{Cd}$ & 0.012 \\
$\mathrm{~Pb}$ & 0.046 \\
\hline
\end{tabular}

\section{Conclusion}

The highest nutrient concentration was measured in LP from Tilu Mountain $(\mathrm{Cu}, \mathrm{Na}, \mathrm{K}$, $\mathrm{Mg}$ and $\mathrm{Zn}$ ). The highest values of $\mathrm{Ba}, \mathrm{Ca}, \mathrm{Co}, \mathrm{Cr}$ and $\mathrm{Fe}$ were detected in LP from Raub. Ni and $\mathrm{Rb}$ were highest in LP from Cibeundey Village. As was highest in LP from Raub $(0.04 \pm 0.00 \mathrm{mg} / \mathrm{kg})$. The highest $\mathrm{Pb}$ contents were in LP from Tilu Mountain $(2.90 \pm 0.10 \mathrm{mg} / \mathrm{kg})$ and LP from Halimunan-Salak Mountain $(3.12 \pm 0.03 \mathrm{mg} / \mathrm{kg}$ ), all of which were well within the permissible limits as specified by the U.S. FDA for edible plant parts. The method has been validated using certified reference material, assessing its quality in terms of accuracy, repeatability and detection limit.

\section{Acknowledgement}

Authors were supported by the Universiti Malaysia Pahang Graduate Research Scheme
090312. This work was partially funded by the Ministry of Science, Technology \& Innovation Malaysia (BTK-013). Useful discussions with Dr. Noumie L. Surugau (Universiti Malaysia Sabah) and Ms. Tay Joo Hui (Universiti Malaysia Pahang) are gratefully acknowledged.

\section{References}

[1] W. Jia and L. Zhang, "Challenges and Opportunities in the Chinese Herbal Drug Industry," in Natural Products: Drug discovery and therapeutic medicine, Zhang, L., New Yoirk: Springer, 2005, pp. 229250.

[2] J. T. Dwyer et al., "Progress in developing analytical and label-based dietary supplement databases at the NIH Office of Dietary Supplements," J. Food Compos. Anal., vol. 21, no. 1, pp. S83-S93, 2008.

[3] P. Kalny, Z. Fijałek, A. Daszczuk, and P. Ostapczuk, "Determination of selected microelements in polish herbs and their infusions," Sci. Total Environ., vol. 381, no. 1-3, pp. 99-104, 2007.

[4] World Health Organization, Food nutritional quality: Micronutrients: Recommended nutrient intakes. World Food Programme, 2002.

[5] S. Millour, L. Noël, A. Kadar, R. Chekri, C. Vastel, and T. Guérin, "Simultaneous analysis of 21 elements in foodstuffs by ICP-MS after closed-vessel microwave digestion: Method validation," J. Food Compos. Anal., vol. 24, no. 1, pp. 111-120, 2011.

[6] I. H. Burkill, A dictionary of the economic products of the Malay Peninsula, Vol. II. London: Crown Agents for the Colonies, 1935.

[7] M. Fazliana, H. F. Gu, C.-G. Östenson, M. M. Yusoff, and W. M. Wan Nazaimoon, "Labisia pumila extract down-regulates hydroxysteroid (11-beta) dehydrogenase 1 expression and corticosterone levels in ovariectomized rats," J. Nat. Med., vol. 66, no. 2, pp. 257-264, 2011.

[8] R. Chizzola and C. H. France, "Metallic trace elements in medicinal and aromatic plants from Austria," J. Appl. Biol., vol. 70, no. 1, pp. 52-56, 1996.

[9] I. Lavilla, A. V Filgueiras, and C. Bendicho, "Comparison of Digestion Methods for Determination of Trace and Minor Metals in Plant Samples," J. Agric. Food Chem., vol. 47, no. 12, pp. 5072-5077, 1999. 
[10] R. Murray, V. Rodwell, D. Bender, and K. M. Botham, Harper's Illustrated Biochemistry, 28th Editi. New York: McGraw-Hill Medical, 2009.

[11] I. Kaya and N. İncekara, "Contents of some wild plants species consumed as food in Aegean region," J. Turkish Weed Sci., vol. 3, pp. 56-64, 2000.

[12] D. A. Eastmond, J. T. MacGregor, and R. S. Slesinski, "Trivalent Chromium: Assessing the Genotoxic Risk of an Essential Trace Element and Widely Used Human and Animal Nutritional Supplement," Crit. Rev.
Toxicol., vol. 38, no. 3, pp. 173-190, 2008.

[13] P. R. Pehrsson, D. B. Haytowitz, and J. M. Holden, "The USDA's National Food and Nutrient Analysis Program: update 2002," J. Food Compos. Anal., vol. 16, no. 3, pp. 331-341, 2003.

[14] M. J. McLaughlin, D. R. Parker, and J. M. Clarke, "Metals and micronutrients - food safety issues," F. Crop. Res., vol. 60, no. 12, pp. 143-163, 1999. 